\title{
Local Binary Pattern untuk Pengenalan Jenis Daun Tanaman Obat menggunakan K-Nearest Neighbor
}

\author{
Zulfrianto Y. Lamasigi ${ }^{\mathrm{a}, 1^{*}}$, Maryam Hasan ${ }^{\mathrm{a}, 2}$ danYulianti Lasena $\mathrm{a}^{\mathrm{a}, 3}$ \\ ${ }^{a}$ Universitas Ichsan Gorontalo, Jl. Achmad Nadjamudin No. 17, Kota Gorontalo 96115 , Indonesia \\ ${ }^{I}$ zulfrianto.dsn@unisan.ac.id; ${ }^{2}$ maryamhasan366@gmail.com; ${ }^{3}$ likhochay@gmail.com \\ *corresponding author
}

\begin{abstract}
INFORMASI ARTIKEL ABSTRAK
Dikirim : 19 Oktober $2020 \quad$ Tanaman obat tradisional merupakan jenis tanaman yang mengandung zat aktif

Diulas : 06 November $2020 \quad$ yang berfungsi mengobati ataupun mencegah dari berbagai macam penyakit.

Direvisi : 06 Desember 2020 Oleh karena itu dilakukan penelitian untuk menguji metode Local Binary

Diterbitkan : 28 Desember $2020 \quad$ Pattern untuk ektraksi ciri dari setiap tanaman obat tradisional dan K-Nearest

KataKunci: $\quad$ Neighbor pada proses klasifikasi setelah dilakukan ektraksi dari metode Local

Local binary Pattern Binary Pattern. Dari pengujian menggunakan metode Local Binary Pattern dan

Tanaman Obat K-Nearest Neighbor mampu menghasilkan akurasi yang cukup baik yaitu

K-Nearest Neighbor $\quad$ sebesar $96.67 \%$, nilai akurasi tersebut didapat dari perhitungan manual

Euclidean Distance convusion matrix dengan nilai k=9. Sementara itu hasil akurasi terendah ada

Confusion Matrix $\quad$ pada nilai $\mathrm{k}=1$ yaitu $0 \%$. Hasil ektraksi dan klasifikasi dari metode Local Binary Pattern dan K-Nearest Neighbor menggunakan 120 dataset yang dibagi menjadi 90 data training dengan 6 jenis daun tanaman obat yang terdiri dari 15 daun bayam duri, 15 daun binahong, 15 daun jarak, 15 daun afrika, dan 15 daun sirih dengan percobaan 30 data testing.
\end{abstract}

\section{Keywords:}

Local binary Pattern

Medicinal plants

K-Nearest Neighbor

Euclidean Distance

Confusion Matrix

\begin{abstract}
Traditional medicinal plants are types of plants that contain active substances that function to treat and are used by the community to cure or prevent various diseases. Therefore, a study was conducted to test the Local Binary Pattern method for feature extraction of each existing traditional medicinal plant and K-Nearest Neighbor for the classification process after extraction from the Local Binary Pattern method. From testing the Local Binary Pattern and KNearest Neighbor methods were able to produce a good accuracy of $96.67 \%$, the accuracy value was obtained from manual convusion matrix calculations with a value of $\mathrm{k}=9$. Meanwhile, the lowest accuracy results are at $\mathrm{k}=1$ with an accuracy value of $70 \%$. The extraction and classification results from the Local Binary Pattern and K-Nearest Neighbor methods used 120 datasets which were divided into 90 training data with 6 types of medicinal plant leaves consisting of 15 thorn spinach leaves, 15 binahong leaves, 15 castor leaves, 15 African leaves, and 15 betel leaves with 30 experimental data testing.
\end{abstract}

This is an open access article under the CC-BY-SA license.

\section{Pendahuluan}

Tanaman obat merupakan jenis tanaman yang mengandung zat aktif berfungsi mengobati dan digunakan oleh masyarakat untuk menyembuhkan dan atau mencegah dari berbagai penyakit [1]. Dari segi konsumsi tanaman obat bisa dimanfaatkan dalam berbagai bentuk, seperti sebagai pelengkap bumbu dapur, sebagai bahan baku makanan dan minuman, serta sebagai tanaman yang dapat dimanfaatkan untuk bahan baku kosmetik [2].

Tanaman obat tradisional jika dibandingkan dengan obat-obatan modern saat ini baik dari segi ketersediaan dan juga biaya, tanaman obat tradisional lebih mudah didapatkan apalagi bagi masyarakat yang tinggal didaerah pedesaan serta tidak perlu mengeluarkan biaya untuk mendapatkannya.Secara global juga sudah terjadi perubahan pola pengobatan masyarakat ke obat-obat tradisional yang terbuat dari bahan alami atau herbal [2].Faktor yang menyebabkan adanya istilah back to nature yakni adanya kegagalan penggunaan obat modern untukpenyakit tertentu di antaranya kanker serta semakin luas akses informasi mengenai obat herbal di 
seluruh dunia, hal ini disebabkan karena obat tradisional atau herbal memiliki efek samping yang relatif lebih rendah bila digunakan secara benar dan tepat serta sesuai untuk penyakit metabolik dan degeneratif [3].

Dua proses yang akan dilakukan untuk pengenalan jenis daun tanaman obat yaitu (1) membuat database tanaman obat berdasarkan pada data citra latih menggunakan metode Local Binary Pattern untuk mendapat ciri dari setiap jenis tanaman obat tradisional, dan (2) mencari ciri jenis daun tanaman obat menggunakan metode Local Binary Pattern pada data citra uji kemudian diklasifikasikan menggunakan algoritma K-Nearest Neighbor. Salah satu metode ekstraksi fitur yang sering digunakan adalah Grey Level Co-Occurrence Matrix (GLCM), Ivarian Moment dan Local Binary Pattern, namun pada penelitian ini, metode ektraksi fitur yang akan digunakan adalahLocal Binary Pattern. Dikarenakan Local Binary Pattern merupakan metode yang paling akurat untuk identifikasi tekstur [4][5][6].

Penelitian sebelumnya yang pernah dilakukan oleh "F.S. Nimah, T. Sutojo, dan D.R.I. Setiadi" menggunakan Grey Level Co-Occurrencen Matrix dan K-Nearest Neighbour untuk identifikasi tumbuhan herbal berdasarkan citra daun dengan hasil akurasi 83,33\%[6], dan "K. Saputra S dan S. Wahyuni” melakukan penelitian identifikasi jenis tanaman herbal berdasarkan ekstraksi fitur morfologi daun menggunakan $K$ Nearest Neighbour dengan hasil akurasi 92\% [7], sementara itu penelitian yang dilakukan oleh "A. Novita E.P. Purwadi dan F.F Coastera" meneliti tentang identifikasi citra daun tanaman jeruk dengan local binary patern dan momeni invariant dengan hasil akurasi sebesar 85,71\% [8].

Berdasarkan ketiga penelitian di atas belum ada yang mengkombinasikan fitur ekstraksi Local Binary Patern dan klasifikasi K-Nearest Neighbour untuk identifikasi daun, sehingga dari penjabaran di atas ditarik kesimpulan untuk melakukan penelitian yang berjudul "Local Binary Pattern Untuk Pengenalan Jenis Daun Tanaman Obat Menggunakan K-Nearest Neighbour" tujuan dari penelitian ini untuk melihat hasil akurasi dari pengaruh Local Binary Pattern terhadap identifikasi jenis daun obat menggunakanK-Nearest Neighbour. pada peneletian ini data yang digunakan merupakan data citra dari 6 (enam) jenis daun tanaman obat diantaranya, daun sambiloto, daun sirih, daun binahong, daun bayam duri, daun afrika, dan daun jarak. jumlah data yang digunakan sebanyak 120 citra daun yang kemudian dibagi menjadi 90 data citra training, dan 30 untuk data citra testing. Terdapat beberapa tahapan dalam penelitian ini, tahap pertama preprocess, selanjutnya tahapan segmentasi untuk melakukan pembagian objek, kemudian dilakukan proses equalization histogram untuk menyesuaikan kontras dari citra daun, kemudian dilanjutkan dengan proses ekstraksi fitur local binary pattern, setelah selesai data siap dimasukkan dalam classifier.

\section{Metode}

\section{A. Histogram Equalization}

Histogram equalization merupakan suatu metode penyesuaian kontras menggunakan histogram dari citra daun dari tanaman obat tradisional. Nilai histogram equalization didapatkan dengan cara memperlebar puncak dan memperkecil titik minimum dari histogram citra supaya penyebaran nilai piksel pada tiap citra merata (uniform), sehingga memperbaiki kekontrasan citra secara keseluruhan [9]. Contoh histogram dapat dilihat pada Gambar 1.

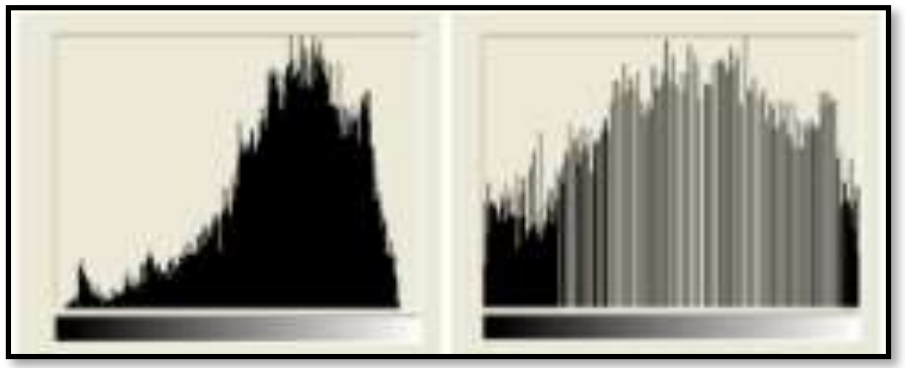

\section{B. Local binary pattern (LBP)}

Gambar 1. Histogram Equalization[9]

Metode Local Binary Pattern diperkenalkan pertama kali oleh Ojala et al [4], [5], [6], dan merupakan salah satu metode ekstraksi fitur yang digunakan untuk mendapatkan fitur tekstur dari sebuah citra, cara kerja metode ini yaitu, dengan menjadikan satu piksel gambar sebagai threshold [4], [7]. Kemudian membandingkannya dengan tetangga dari piksel pada matrix 3x3 dengan nilai tengah matrix sebagai ambang pusat [4]. Dimana, jika nilai biner piksel pusat lebih besar dengan nilai disekelilingnya maka akan diberi nilai 1, sebaliknya jika nilai biner piksel pusat lebih kecil dengan nilai disekelilingnya maka akan diberi nilai 0 [4], [7], [12]. Selanjutnya dari hasil uji biner yang di dapat dari perbandingan tersebut disimpan dalam array 8 bit yang diubah menjadi desimal untuk menggantikan nilai piksel pusat [7], [9]. Dari penjelasan tersebut di dapatkan langkah-langkah metode Local Binary Pattern seperti yang ditunjukkan Gambar 2, Gambar 3 dan Gambar 4. 


\begin{tabular}{|l|l|l|}
\hline 5 & 8 & 1 \\
\hline 5 & 4 & 1 \\
\hline 3 & 7 & 2 \\
\hline
\end{tabular}

\begin{tabular}{|l|l|l|}
\hline 0 & 0 & 1 \\
\hline 0 & & 1 \\
\hline 1 & 0 & 1 \\
\hline
\end{tabular}

Gambar 2. Langkah pertama

\begin{tabular}{||l|l|l|}
\hline 0 & 0 & 1 \\
\hline 0 & & 1 \\
\hline 1 & 0 & 1 \\
\hline
\end{tabular} \mid \begin{tabular}{|c|c|c|c|c|c|c|c|}
$2^{8}$ & $2^{7}$ & $2^{6}$ & $2^{5}$ & $2^{4}$ & $2^{3}$ & $2^{1}$ & $2^{0}$ \\
\hline 0 & 0 & 0 & 1 & 0 & 1 & 1 & 1 \\
\hline 0 & $16+4+2+1=23$ &
\end{tabular}

Gambar 3. Langkah Kedua

\begin{tabular}{|l|l|l|l|l|}
\hline 5 & 4 & 2 & 2 & 1 \\
\hline 3 & 5 & 8 & 1 & 3 \\
\hline 2 & 5 & 4 & 1 & 2 \\
\hline 4 & 3 & 7 & 2 & 7 \\
\hline 1 & 4 & 4 & 2 & 6 \\
\cline { 3 - 4 }
\end{tabular}

Gambar 4. Langkah ketiga

Jika koordinat dari piksel pusat adalah $\left(x_{c}, y_{c}\right)$ maka koordinat dari tetangga $\mathrm{P}\left(x_{p}, y_{p}\right)$ pada tepi lingkaran dengan jari-jari R dapat ditentukan dengan persamaan (1) dan persamaan (2) [10].

$$
\begin{aligned}
& x_{P}=x_{c}+R \cos \left(\frac{2 \pi p}{p}\right) \\
& y_{P}=y_{c}+R \sin \left(\frac{2 \pi p}{p}\right)
\end{aligned}
$$

Perhitungan metode Local Binary Pattern dapat pula di selesaikan dengan persamaan (3) dan persamaan (4) [4], [9][10].

$$
\begin{aligned}
L B P_{P, R}\left(x_{c}, y_{c}\right. & =\sum_{P=0}^{P=1} s\left(g_{p}-g_{c}\right) 2^{p} \\
s(x) & =\left\{\begin{array}{c}
x \geq 0 \\
x,
\end{array} \quad \begin{array}{c}
x< \\
0,
\end{array}\right.
\end{aligned}
$$

Keterangan:

$$
\begin{array}{ll}
P & \text { :banyaknya piksel tetangga } \\
R & \text { :nilai jarak/radius } \\
g_{c} & \text { :nilai dari piksel } x \text { dan } y \\
g_{p} & \text { :nilai piksel tetangga } \\
x_{c}, y_{c} & \text { :koordinat pusat. }
\end{array}
$$

Local Binary Pattern disebut seragam jika memiliki paling banyak perpindahan dua bitwise dari 0 ke 1 , atau sebaliknya, sehingga pola yang seragam memiliki pola tanpa perpindahan atau dua perpindahan. Jumlah kemungkinan pola dengan dua perpindahan adalah $P(P-1)$. Pola seragam dengan titik cuplik $\mathrm{P}$ dan jari-jari $\mathrm{R}$ digunakan notasi $L B P_{P, R}^{u 2}$.

- Penggunaan satuan harus konsisten dan tidak menggabunggkan singkatan dan abreviasi. Contoh: " $\mathrm{Wb} / \mathrm{m}^{2}$ " atau "weber per meter kuadrat", dan bukan" weber $/ \mathrm{m}^{2}$ ",

- Perhatikan penulisan bilangan desimal, seperti: “ 0.25 ,” bukan ".25."

\section{K-Nearest Neighbour (K-NN)}

K-Nearest Neighbor merupakan salah satu algoritma klasifikasi Supervised learning[4], [11], [12], yang bertujuan untuk mengklasifikasikan objek baru berdasarkan atribut atau ciri dari sampel data latih yang sudah 
ada pada sistem [4], [11], Dengan berdasarkan jarak ketetanggaan terdekat dari data uji ke data latih [4]. Beikut merupakan langkah-langkah perhitungan algoritma K-NN [13].

1. Menentukan nilai $\mathrm{K}$ atau tentangga terdekat dari data latih terhadap data uji.

2. Menghitung jarak dengan Euclidean distance masing-masing objek terhadap data latih yang diberikan.

3. Kemudian mengurutkan objek-objek tersebut dari yang terkecil ke terbesar.

4. Mengelompokkan data sejumlah K yang telah ditentukan sebelumnya.

5. Memilih kategori yang paling mayoritas atau yang paling banyak muncul.

Algoritma K-Nearest Neighbor pada penelitian ini menggunakan salah satu perhitungan jarak yaitu, jarak Euclidean Distance, karena perhitungan jarak Euclidean yang paling umum digunakan pada data yang berbentuk numerik [11]. Jarak Euclidean dapat didefinisikan sebagai jarak antara dua titik pada data latih dan titik pada data uji dengan persamaan (5) [14]:

Keterangan:

$$
d=\sqrt{\sum_{i=1}^{p}\left(x_{2 i}-x_{1 i}\right)^{2}}
$$

$$
\begin{array}{ll}
d & : \text { jarak Euclidean } \\
x_{2 i} & \text { : nilai pada data uji ke- } i \\
x_{1 i} & \text { : nilai pada data latih ke-i } \\
p & \text { : banyaknya atribut }
\end{array}
$$

Berikut merupakan tabel pembahasan dari studi kasus pemilihan studi jurusan teknik informatika dengan perhitungan jarak euclidean menggunakan metode K-Nearest Neighbor [15].

\section{Confusion Matrix}

Confusiion Matrix merupakan salah satu alat ukur yang terdiri dari dua kelas, yaitu kelas positif dan negative yang berbentuk matrix dan digunakan untuk mendapatkan jumlah ketepatan klasifikasi terhadap kelas dikenali atau tidak dikenali jenis daun tanaman obat pada algoritma yang akan dipakai pada penelitian ini, Tabel 1 merupakan tabel confusion matrix[12], [16].

Table 1. Confusion Matrix

\begin{tabular}{|ccc|}
\hline \multirow{2}{*}{ Klasifikasi yang benar } & \multicolumn{2}{c|}{ Disklasifikasikan sebagai } \\
\cline { 2 - 3 } & + & - \\
\hline+ & True positive & False negative \\
\hline- & False positive & True negative \\
\hline
\end{tabular}

True positive adalah jumlah data uji yang dimasukkan ke dalam klasifikasi yang benar sebagai positif, False positive adalah jumlah data uji yang dimasukkan ke dalam klasifikasi yang benar sebagai positif. Sedangkan False negative adalah jumlah data uji yang dimasukkan ke dalam klasifikasi yang benar sebagai negative, True negative adalah jumlah data uji yang dimasukkan ke dalam klasifikasi yang benar sebagai negative. Kemudian dari penjelasan tersebut dapat diperoleh beberapa pengukuran evaluasi diantaranya accuracy persamaan (6), precision persamaan (7), dan recall persamaan (8) [16].

$$
\begin{gathered}
\text { Accuracy }=\frac{T P+T N}{T P+F P+T N+F N} \\
\text { Precision }=\frac{T P}{T P+F P} \\
\text { Recall }=\frac{T P}{T P+F N}
\end{gathered}
$$

Keterangan:

True Positive (TP) :Jumlah anggota class 1 yang berhasil diprediksi dengan benar.

False Positive (FP) :Jumlah anggota class 1 yang gagal diprediksi dengan benar.

True Negative (TN) :Jumlah anggota class 0 yang berhasil diprediksi dengan benar.

False Negative (FN) :Jumlah anggota class 0 yang gagal diprediksi dengan benar. 
Tingkat akurasi sebuah klasifikasi merupakan rasio perbandingan jumlah data uji yang dapat disklasifikasikan dengan benar dengan jumlah seluruh data uji. Adapun persamaan untuk mencari tingkat akurasi yang lain dinyatakan pada persaman (9) [14].

$$
\text { Akurasi }=\frac{\text { Banyaknya prediski yang benar }}{\text { Total banyak prediksi }} \times 100 \%
$$

\section{Hasil dan Pembahasan}

Penelitian ini memiliki tujuan untuk melihat hasil akurasi dari pengaruh Local binary pettern (LBP) untuk pengenalan jenis daun obat menggunakan K-Nearest neighbor (K-NN), data set yang digunakan merupakan daun tanaman obat tradisional, jumlah dari data sebanyak 120 yang di bagi menjadi, 90 untuk data training dan 30 untuk data testing. Tabel 2 merupakan data citra jenis daun obat tradisional.

Tabel 2. Data Jenis Daun Obat

Data Jenis Daun Obat
Daun Afrika
Duri

Langkah awal atau preprocessing yang dilakukan adalah dengan menguah citra RGB kedalam bentuk citra Greyscale, selanjutnya dilakukan proses equalization Histogram seperti yang di perlihatkan pada Tabel 3.

Table 3. Hasil konversi RGB ke Grayscale dan Grayscale ke Histogram Equalization

\begin{tabular}{|c|c|c|}
\hline \multicolumn{2}{c}{ Konversi Rgb Ke Grayscale Dan Grayscale Ke Histogram Equalization } \\
\hline Citra RGB & Citra Grayscale & Citra Histogram \\
\hline & & \\
& & \\
\hline
\end{tabular}

Selanjutnya dilakukan tahapan segmentasi yang bertujuan untuk membagi objek kedalam beberapa bagian sebelum dilakukannya tahapan ekstraksi fitur dengan menggunakan Local Binary Pattern. Pada Tabel 4 diperlihatkan sampel segmentasi citra daun.

Tabel 4. Hasil Segmentasi

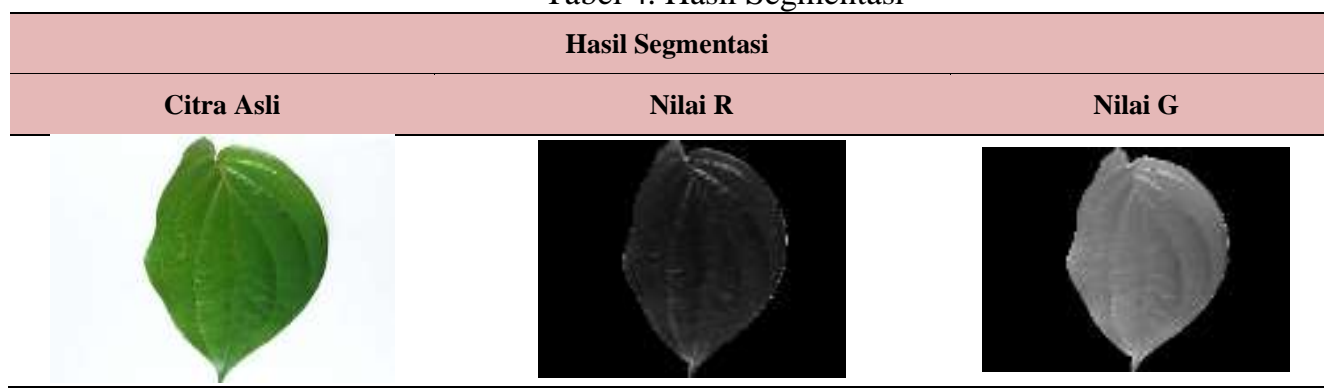




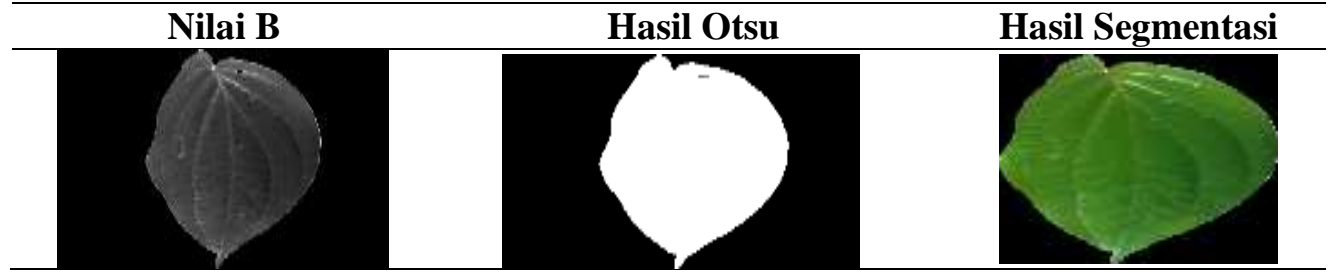

Setelah tahapan segmentasi selesai dilakukan maka selanjutkan dilakukan proses ekstraksi fitur dengan menggunakan algoritma Local Binary Pattern (LBP), Proses ekstrasi fitur ini dilakukan untuk mengetahui setiap ciri dari sebuah tekstur dari masing-masing jenis daunobat sebelum dilakukannya proses klasifikasi dengan K-Nearest neighbour. Berikut contoh perhitungan manual metode LBP dengan ukuran piksel 10x10 yang diambil dari citra daun jarak disajikan pada Tabel 5.

Tabel 5. Piksel 10x10 citra daun jarak

\begin{tabular}{ccccccccccc}
\hline \multirow{2}{*}{$(\boldsymbol{x}, \boldsymbol{y})=$} & \multicolumn{8}{c}{ Perhitungan metode LBP pada citra 10x10 piksel } \\
\cline { 2 - 10 } $\boldsymbol{x}, \boldsymbol{1}$ & $\mathbf{1}$ & $\mathbf{3}$ & $\mathbf{4}$ & $\mathbf{5}$ & $\mathbf{6}$ & $\mathbf{7}$ & $\mathbf{8}$ & $\mathbf{9}$ & $\mathbf{1 0}$ \\
\hline $\mathbf{1}$ & 253 & 253 & 254 & 254 & 106 & 178 & 253 & 251 & 251 & 250 \\
\hline $\mathbf{3}$ & 253 & 253 & 253 & 246 & 100 & 121 & 135 & 248 & 250 & 250 \\
\hline $\mathbf{4}$ & 251 & 253 & 253 & 98 & 79 & 93 & 88 & 94 & 250 & 248 \\
\hline $\mathbf{5}$ & 250 & 251 & 253 & 93 & 100 & 75 & 77 & 78 & 250 & 248 \\
\hline $\mathbf{6}$ & 250 & 251 & 253 & 108 & 93 & 83 & 75 & 75 & 250 & 247 \\
\hline $\mathbf{7}$ & 250 & 251 & 253 & 98 & 81 & 83 & 80 & 72 & 250 & 248 \\
\hline $\mathbf{8}$ & 250 & 251 & 253 & 254 & 104 & 79 & 88 & 253 & 251 & 250 \\
\hline $\mathbf{9}$ & 250 & 253 & 253 & 253 & 126 & 114 & 253 & 253 & 253 & 251 \\
\hline
\end{tabular}

Setelah proses ekstraksi fitur dengan Local binary patter selesai dilakukan maka selanjutnya dilakukan proses klasifikasi dengan menggunakan $K$-Nearest neighbor. Pada tahapan ini, hasil dari ekstraksi fitur data training dan data testing pada pembahasan sebelumnya diklasifikasikan berdasarkan kelasnya masing-masing dengan percobaan jumlah $\mathrm{k}=1, \mathrm{k}=3, \mathrm{k}=5, \mathrm{k}=7$, dan $\mathrm{k}=9$, nilai dari jumlah $\mathrm{k}$ tersebut diambil berdasarkan nilai angka ganjil agar dapat menghindari hasil klasifikasi dengan jumlah data yang seimbang. Nilai $\mathrm{k}$ tersebut juga dapat menentukan bagaimana kinerja algoritma $K$-Nearest Neighbour, dalam melakukan pengenalan jenis daun tanaman obat, seperti yang terlihat pada Tabel 6.

Table 6. Hasil ekstraksi fitur dari data training

\begin{tabular}{|c|c|c|c|c|c|c|c|c|c|}
\hline \multicolumn{10}{|c|}{ Hasil Aktraksi fitur data training } \\
\hline No & Data & $\mathbf{X 1}$ & $\mathbf{X} 2$ & $\mathbf{X 3}$ & $\ldots$ & X8 & X9 & $\mathbf{X 1 0}$ & $\mathbf{Y}$ \\
\hline $\mathbf{0}$ & & 0.047 & 0.056 & 0.028 & $\cdots$ & 0.06 & 0.488 & 0.107 & $\begin{array}{l}\text { Daun } \\
\text { Afrika }\end{array}$ \\
\hline 1 & & 0.036 & 0.046 & 0.019 & $\ldots$ & 0.051 & 0.583 & 0.088 & $\begin{array}{l}\text { Daun } \\
\text { Afrika }\end{array}$ \\
\hline
\end{tabular}




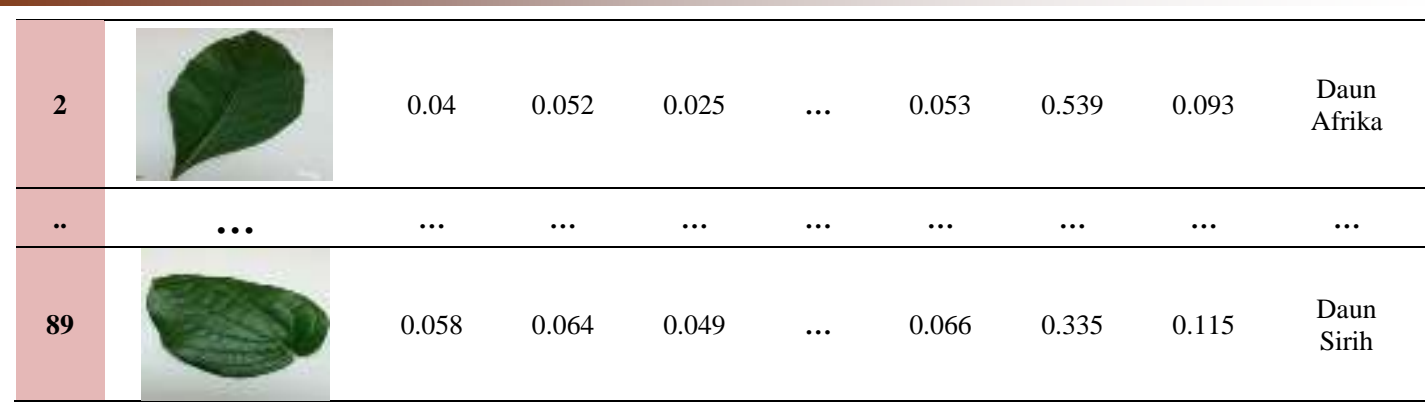

Tabel 7. Hasil ekstraksi fitur data testing

\begin{tabular}{l}
\multicolumn{10}{c}{ Hasil Ekstraksi Fitur Data Training } \\
$\mathrm{X} 1$
\end{tabular}

Untuk mengetahuikelas dari data testing pada Tabel 7 dilakukan perhitungan dengan rumus perhitungan jarak Euclidean Distance seperti yang terlihat pada persamaan (10).

$$
d=\sqrt{\sum_{i=1}^{p}\left(x_{2 i}-x_{1 i}\right)^{2}}
$$

Penyelesaian:

$$
\begin{gathered}
d=\sqrt[\begin{array}{c}
(0.047-0.046)^{2}+(0.056-0.064)^{2}+(0.028-0.05)^{2} \\
+(0.045-0.048)^{2}+(0.076-0.104)^{2}+(0.051-0.079)^{2}+ \\
(0.041-0.06)^{2}+(0.06-0.067)^{2}+(0.488-0.345)^{2}+ \\
(0.107-0.102)^{2}
\end{array}]{=\sqrt{\begin{array}{c}
(0.001)^{2}+(-0.008)^{2}+(-0.022)^{2}+(-0.039)^{2}+(-0.028)^{2}+ \\
(-0.028)^{2}+(-0.019)^{2}+(-0.007)^{2}+(0.143)^{2}+(0.005)^{2}
\end{array}}} \\
=\sqrt{\begin{array}{c}
0.000001+0.000064+0.000484+0.001521+ \\
0.000784+0.000784+0.000361+0.000049+ \\
0.020449+0.000025
\end{array}} \\
=\sqrt{0.024522}=0.156
\end{gathered}
$$

\begin{tabular}{|c|c|c|c|}
\hline \multirow{2}{*}{ Data } & \multicolumn{3}{|c|}{ Perhitungan jarak Euclidean Distance } \\
\hline & Jarak Euclidean Distance & Nilai & Kelas \\
\hline 0 & $d=\sqrt{(0.047-0.046)^{2}+\cdots(0.107-0.102)^{2}}$ & 0.1567 & Daun Afrika \\
\hline 1 & $d=\sqrt{(0.036-0.046)^{2}+\cdots(0.088-0.0102)^{2}}$ & 0.2537 & Daun Afrika \\
\hline 2 & $d=\sqrt{(0.04-0.046)^{2}+\cdots(0.093-0.102)^{2}}$ & 0.2077 & Daun Afrika \\
\hline 6 & $d=\sqrt{(0.046-0.046)^{2}+\cdots(0.107-0.102)^{2}}$ & 0.1577 & Daun Afrika \\
\hline 7 & $d=\sqrt{(0.04-0.046)^{2}+\cdots(0.093-0.102)^{2}}$ & 0.1612 & Daun Afrika \\
\hline$\ldots$ & $\ldots$ & $\ldots$ & $\ldots$ \\
\hline
\end{tabular}

Kemudian dari proses perhitungan jarak yang telah dilakukan maka nilai yang didapatkan dari perhitungan jarak antara data training dengan data testing tersebut akan disusun berdasarkan nilai pada masing-masing kelas seperti pada Tabel 8 .

Tabel 8. Perhitungan Jarak Euclidean Distance 


$90 \quad d=\sqrt{(0.058-0.046)^{2}+\cdots(0.115-0.102)^{2}} \quad 0.0217 \quad$ Daun Sirih

Setelah nilai jarak dari masing-masing data training ke data testing didapatkan maka akan disusun berdasarkan nilai terkecil. Berikut adalah penentuan kelas dari data testing dengan nilai $\mathrm{k}=1, \mathrm{k}=3, \mathrm{k}=5, \mathrm{k}=7$, dan $\mathrm{k}=9$, disajikan pada Tabel 9.

Tabel 9. Hasil pengurutan dari nilai terkecil ke terbesar

\begin{tabular}{ccc} 
& \multicolumn{2}{c}{ Pengurutan Nilai Terkecil ke Terbesar } \\
\cline { 2 - 3 } $\begin{array}{c}\text { Data } \\
\text { ke }\end{array}$ & $\begin{array}{c}\text { Perhitungan jarak Euclidean } \\
\text { Distance }\end{array}$ & Kelas \\
\hline 89 & 0.02168 & Daun Sirih \\
\hline 80 & 0.02379 & Daun Sirih \\
\hline 88 & 0.02557 & Daun Sirih \\
\hline 24 & 0.02753 & Daun Bayam Duri \\
\hline 20 & 0.03159 & Daun Bayam Duri \\
\hline 76 & 0.0372 & Daun Sirh \\
\hline 75 & 0.04351 & Daun Sirih \\
\hline$\ldots$ & $\ldots$ & $\ldots$ \\
\hline 61 & 0.42947 & Daun Sambiloto \\
\hline
\end{tabular}

Dari hasil pengurutan yang terdapat pada Tabel 9 maka yang akan diambil adalah nilai berdasarkan jumlah $\mathrm{k}$ yang telah ditentukan sebelumnya, yakni nilai $\mathrm{k}=1, \mathrm{k}=3, \mathrm{k}=5, \mathrm{k}=7$, dan $\mathrm{k}=9$. Dari hasil pengurutan berdasarkan nilai $\mathrm{k}$, hasil klasifikasi dengan nilai $\mathrm{k}=1, \mathrm{k}=3, \mathrm{k}=5, \mathrm{k}=7$, dan $\mathrm{k}=9$ maka dapat dinyatakan bahwa kelas yang paling mayoritas/mirip dengan data uji adalah "Daun Sirih", seperti disajikan pada Tabel 10.

Tabel 10. Kelas dari data testing adalah "Daun Sirih".

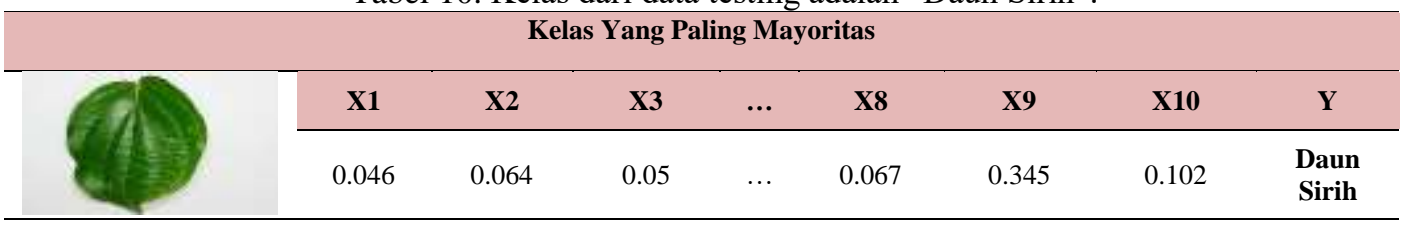

Setelah tahapan klasifikasi K-Nearest Neighbour selesai dilakukan maka dilanjutkan dengan proses evaluasi dengan menggunakan Confusion Matrix, tujuan dari evaluasi yaitu untuk mendapatkan nilai atau hasil akurasi dari klasifikasi K-Neares Neighbour. Berikut merupakan tabel dari hasil perhitungan 30 data testing dengan nilai akurasi terendah ada pada $\mathrm{k}=1$ sebesar $70 \%$ dan nilai akurasi tertinggi ada pada $\mathrm{k}=9$ sebesar $96.67 \%$ yang di perlihatkan pada Tabel 11 dan Tabel 12 .

Table 11. Perhitungan Confusion Matrix dengan nilai $\mathrm{k}=1$

\begin{tabular}{cccccc}
\hline Kelas & \multicolumn{3}{c}{ Evaluasi Confusion Matrix k=1 } \\
\cline { 2 - 6 } & $\begin{array}{c}\text { Daun } \\
\text { Bayam } \\
\text { Duri }\end{array}$ & $\begin{array}{c}\text { Daun } \\
\text { Binahong }\end{array}$ & $\begin{array}{c}\text { Daun } \\
\text { Jarak }\end{array}$ & $\begin{array}{c}\text { Daun } \\
\text { Afrika }\end{array}$ & $\begin{array}{c}\text { Daun } \\
\text { Sambiloto }\end{array}$ \\
\hline Daun Sirih \\
\hline Daun Binahong & 5 & 0 & 0 & 0 & 0 \\
\hline Daun Jarak & 0 & 5 & 0 & 0 & 0 \\
\hline Daun Afrika & 0 & 0 & 4 & 2 & 0 \\
\hline Daun Sambiloto & 0 & 0 & 1 & 0 & 0 \\
\hline Daun Sirih & 0 & 0 & 0 & 0 \\
\hline
\end{tabular}

Penjelasan warna:

Data uji benar

Data uji salah 
Dari Tabel 11 menunjukkan bahwa dari hasil klasifikasi dengan nilai $\mathrm{k}=1$ berhasil mengenali kelas bayam duri sebanyak 5 kelas, daun binahong sebanyak 5 kelas, daun jarak sebanyak 4 kelas dan 1 dikenali sebagai daun afrika, kemudian daun afrika tidak berhasil dikenali tetapi dikenali sebagai daun jarak sebanyak 2 kelas dan daun sambiloto sebanyak 3 kelas, selanjutnya daun sambiloto berhasil dikenali sebanyak 4 dan 1 dikenali sebagai daun afrika, terakhir daun sirih dikenali sebanyak 3 dan 2 kelas dikenali sebagai daun binahong. Berikut merupakan perhitungan hasil akurasi yang didapat dari jumlah data testing yang berhasil dikenali.

$$
\begin{gathered}
\text { Akurasi }=\frac{\text { Total Data Uji yang benar }}{\text { Total Data Uji }} 100 \% \\
\text { Akurasi }=\frac{(5+5+4+0+4+3)}{30} \times 100 \% \\
\text { Akurasi }=\frac{21}{30} \times 100 \%=70 \%
\end{gathered}
$$

\begin{tabular}{|c|c|c|c|c|c|c|}
\hline \multirow[b]{2}{*}{ Kelas } & \multicolumn{6}{|c|}{ Evaluasi Confusion Matrix k=9 } \\
\hline & $\begin{array}{c}\text { Daun } \\
\text { Bayam } \\
\text { Duri }\end{array}$ & $\begin{array}{c}\text { Daun } \\
\text { Binahong }\end{array}$ & $\begin{array}{l}\text { Daun } \\
\text { Jarak }\end{array}$ & $\begin{array}{l}\text { Daun } \\
\text { Afrika }\end{array}$ & $\begin{array}{c}\text { Daun } \\
\text { Sambiloto }\end{array}$ & Daun Sirih \\
\hline Daun Bayam Duri & 4 & 0 & 0 & 0 & 0 & 1 \\
\hline Daun Binahong & 0 & 5 & 0 & 0 & 0 & 0 \\
\hline Daun Jarak & 0 & 0 & 5 & 0 & 0 & 0 \\
\hline Daun Afrika & 0 & 0 & 0 & 5 & 0 & 0 \\
\hline Daun Sambiloto & 0 & 0 & 0 & 0 & 5 & 0 \\
\hline Daun Sirih & 0 & 0 & 0 & 0 & 0 & 5 \\
\hline
\end{tabular}

Tabel 12. Perhitungan Confusion Matrix dengan nilai k=9

Dari Tabel 12 menunjukkan bahwa dari hasil klasifikasi dengan nilai k=9 berhasil mengenali kelas bayam duri sebanyak 4 kelas dan 1 kelas dikenali sebagai daun sirih, daun binahong dikenali sebanyak 5 kelas, daun jarak dikenali sebanyak 5 kelas, daun afrika dikenali sebanyak 5 kelas, daun sambiloto dikenali sebanyak 5 kelas, terakhir daun sirih dikenali sebanyak 5 kelas. Berikut merupakan perhitungan hasil akurasi yang didapat dari jumlah data testing yang berhasil dikenali.

$$
\begin{gathered}
\text { Akurasi }=\frac{\text { Total Data Uji yang benar }}{\text { Total Data Uji }} 100 \% \\
\text { Akurasi }=\frac{(4+5+5+5+5+5)}{30} \times 100 \% \\
\text { Akurasi }=\frac{29}{30} \times 100=96.67 \%
\end{gathered}
$$

Dari percobaan yang telah dilakukan dengan menggunakan citra asli tanpa dipotong pada proses pengenalan, waktu yang dibutuhkan \pm 14 menit, hal ini terjadi karena jumlah piksel yang terlalu besar dan kapasitas komputer yang masih dibawah menyebabkan lamanya proses pengenalan. Tetapi berbeda dengan proses pengenalan dengan citra yang telah dipotong yang memerlukan waktu \pm 3 menit dalam mengenali citra testing yang diinputkan ke dalam sistem. Oleh karena itu dalam penelitian ini citra yang telah diambil sebelumnya di risize terlebih dahulu dengan ukuran 200x286 piksel untuk mempercepat proses pengenalan.

Tabel 13 merupakan tabel sampel hasil pengenalan dari 30 data testing yang terdiri dari data daun afrika $=5$, data daun bayam duri=5, data daun binahong $=5$, data daun jarak $=5$, data daun sambiloto $=5$, dan data daun sirih $=5$ dengan percobaan nilai $\mathrm{k}=1, \mathrm{k}=3, \mathrm{k}=5, \mathrm{k}=7$, dan $\mathrm{k}=9$ dengan jumlah data training 90 citra, yang terdiri dari data daun afrika $=15$, data daun bayam duri $=15$, data daun binahong $=15$, data daun jarak $=15$, data daun sirih $=15$, dan data daun sambiloto $=15$, dengan masing-masing nilai akurasi dari perhitungan evaluasi confusion matrix. 
Tabel 13. Sampel hasil pengenalan Jenis daun Obat dengan 30 data testing

\begin{tabular}{|c|c|c|c|c|c|}
\hline \multirow{2}{*}{ Data Testing } & \multicolumn{5}{|c|}{ Hasil Pengenalan Jenis Daun Obat } \\
\hline & Nilai $\mathbf{k}=1$ & Nilai $k=3$ & Nilai $k=5$ & Nilai k=7 & Nilai $k=9$ \\
\hline & Daun Binahong & Daun Binahong & Daun Binahong & Daun Binahong & Daun Binahong \\
\hline & Daun Bayam Duri & $\begin{array}{c}\text { Daun Bayam } \\
\text { Duri }\end{array}$ & $\begin{array}{c}\text { Daun Bayam } \\
\text { Duri }\end{array}$ & $\begin{array}{c}\text { Daun Bayam } \\
\text { Duri }\end{array}$ & $\begin{array}{c}\text { Daun Bayam } \\
\text { Duri }\end{array}$ \\
\hline & Daun Jarak & Daun Jarak & Daun Jarak & Daun Jarak & Daun Afrika \\
\hline & Daun Afrika & Daun Afrika & Daun Afrika & Daun Jarak & Daun Jarak \\
\hline & Daun Sirih & $\begin{array}{c}\text { Daun Bayam } \\
\text { Duri }\end{array}$ & $\begin{array}{c}\text { Daun Bayam } \\
\text { Duri }\end{array}$ & $\begin{array}{c}\text { Daun Bayam } \\
\text { Duri }\end{array}$ & Daun Sirih \\
\hline & Daun Sambiloto & Daun Sambiloto & Daun Sambiloto & Daun Sambiloto & Daun Sambiloto \\
\hline $\begin{array}{c}\text { Hasil } \\
\text { Akurasi }\end{array}$ & $70 \%$ & $76.67 \%$ & $80 \%$ & $86.67 \%$ & $96.67 \%$ \\
\hline
\end{tabular}

\section{Kesimpulan}

Hasil akurasi tertinggi dari penerapan metode Local Binary Pattern untuk pengenalan jenis daun tanaman obat tradisional menggunakan algoritma $K$-Nearest Neighbor menghasilkan nilai akurasi sebesar $96.67 \%$ pada jumlah $\mathrm{k}=9$. Dengan demikian nilai $\mathrm{k}=9$ adalah yang paling optimal digunakan sebab dari 30 data testing yang telah diuji coba hanya satu data testing yang tidak dapat dikenali, yaitu daun tanaman bayam duri yang dikenali sebagai daun sirih. Sehinga dapat disimpulkan bahwa pengaruh ekstraksi fitur Local Binary Pattern pada pengenalan Jenis daun obat menggunakan K-Nearest neighbor dapat di implementasikan pada jenis pengenalan objek lainya seperti Motif Batik Ataupun Jenis Ikan.

\section{Daftar Pustaka}

[1] R. Rizwan and M. Muhammad, "Sistem Informasi Tanaman Obat Tradisional Beserta Pengolahannya," 2018.

[2] Z. Salim and E. Munadi, "Info Komoditi Tanaman Obat," 2017.

[3] D. Prasanti, "Peran Obat Tradisional dalam Komunikasi Terapeutik Keluarga di Era Digital," no. 1, pp. 17-27, 2017.

[4] M. I. Sultoni, B. Hidayat, and A. Slamet Subandrio, "Klasifikasi Jenis Batuan Beku Melalui Citra Berwarna Dengan Menggunakan Metode Local Binary Pattern Dan K-Nearest Neighbor," TEKTRIKA J. Penelit. dan Pengemb. Telekomun. Kendali, Komputer, Elektr. dan Elektron., vol. 4, no. 1, p. 10, 2019.

[5] H. Z. Zahro, "Analisis Tekstur Untuk Identifikasi Tumbuhan Obat Menggunakan Klasifikasi Support Vector Machine," Ind. Inov., vol. 6, no. 2, pp. 33-40, 2016.

[6] F. S. Ni'mah, T. Sutojo, and D. R. I. M. Setiadi, "Identifikasi Tumbuhan Obat Herbal Berdasarkan Citra Daun Menggunakan Algoritma Gray Level Co-occurence Matrix dan K-Nearest Neighbor," J. Teknol. dan Sist. Komput., vol. 6, no. 2, p. 51, 2018.

[7] K. Saputra S and S. Wahyuni, "Identifikasi Jenis Tanaman Berdasarkan Ekstraksi Fitur Morfologi Daun Menggunakan K-Nearest Neighbor," vol. 5, no. 1, pp. 24-29, 2020.

[8] A. Novitasari, E. P. Purwandari, and F. F. Coastera, "Identifikasi citra daun tanaman Jeruk dengan Local Binary Pattern dan Moment Invariant," vol. 3, no. September, pp. 76-83, 2018.

[9] E. Wahyudi, H. Kusuma, and Wirawan, "Perbandingan Unjuk Kerja Pengenalan Wajah Berbasis Fitur Local Binary Pattern dengan Algoritma PCA dan Chi Square," pp. 3-8.

[10] K. Mujib, A. Hidayatno, and T. Prakoso, "Pengenalan Wajah Menggunakan Local Binary Pattern(LBP) dan Support Vector Machine(SVM)." 
[11]F. Liantoni, "Klasifikasi Daun Dengan Perbaikan Fitur Citra Menggunakan Metode K-Nearest Neighbor," J. Ultim., vol. 7, no. 2, pp. 98-104, 2016.

[12] D. Putra Pamungkas and A. Bagus Setiawan, "Implementasi Ekstrasi Fitur dan K-Nearest Neightbor untuk Identifikasi Wajah Personal,” vol. 3, no. 2, pp. 187-193, 2018.

[13] S. L. B. Ginting, W. Zarman, and A. Darmawan, "Teknik Data Mining untuk Memprediksi Masa Studi Mahasiswa Menggunakan Algoritma K-Nearest Neighborhood," vol. 3, no. 2, pp. 29-34, 2014.

[14] D. Noviana, Y. Susanti, and I. Susanto, "Analisis Rekomendasi Penerima Beasiswa Menggunakan Algoritma K-Nearest Neighbor(K-NN) dan Algoritma C4.5," 2019.

[15]L. Anshori, R. Regasari Mardi Putri, and Tibyani, "Implementasi Metode K-Nearest Neighbor untuk Rekomendasi Keminatan Studi (Studi Kasus : Jurusan Teknik Informatika Universitas Brawijaya)," no. July, 2018.

[16]A. M. Malik and A. J. P. Sibarani, “Aplikasi Prediksi Kelulusan Ujian Nasional Menggunakan Algoritma K-Nearest Neighbor dengan Pengukuran Jarak Manhattan Distance,” vol. 1, no. 2, pp. 829835. 